\title{
Kyasanur forest disease
}

INSERM

\section{Source}

INSERM. (1999). Orphanet: an online rare disease and orphan drug data base. Kyasanur forest disease. ORPHA:319254

Kyasanura forest disease (KFD), caused by the KFD virus, is an arbovirus characterized by an initial fever, headache and myalgia that can progress to a hemorrhagic disease and that in some cases is followed by a second phase characterized by neurological manifestations. 